
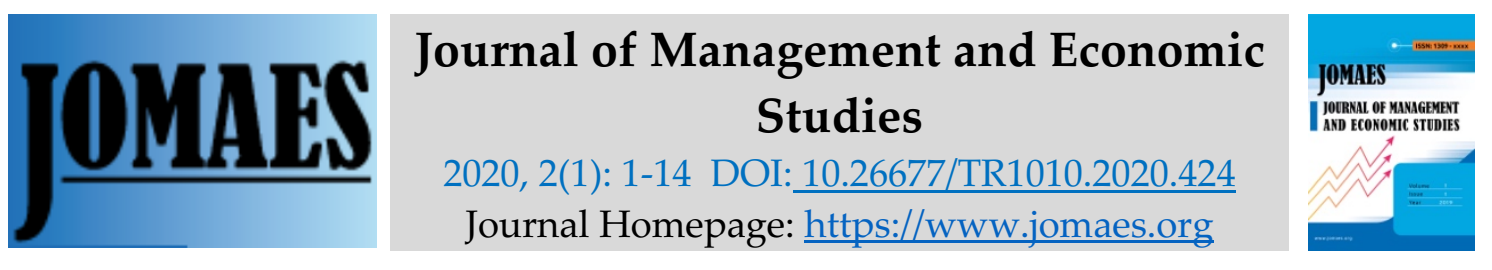

\title{
Evaluating The Financial and Other Implications of Lagos' Multi-Year Prepaid Property Leases
}

\author{
Ndubisi Onwuanyi \\ Department of Estate Management, Faculty of Environmental Sciences, University of Benin, \\ Benin City, Nigeria.ndubisi.onwuanyi@uniben.edu \\ www.orcid.org/0000-0002-8250-3888
}

\begin{abstract}
Real estate investment decisions are rationally made. Thus, the parties to a transaction, whether buying, selling or letting, come to agreement upon the conviction that value will be directly received in exchange. This indicates a uniformity of intention and expectation. However, Lagos lettings usually result in an unequal exchange of value. This occurs where a lessor demands and receives multi-year prepayments which deliver direct and premature value while the lessee effectively receives deferred value. This paper evaluates the practice, financial consequences and other implications of such leases. The findings are that the practice is financially disadvantageous to the tenant, but not to the landlord; has the potential to reduce tenants' savings capacity, investible funds and productivity in the economy; slows down the home ownership growth rate, and effectively worsens the housing deficit; and does not promote the well-being, human and social development of tenants. The paper makes two recommendations: first, the deployment of suasion to discourage the practice; and secondly, massively increasing housing supply through multi-pronged public sector interventions to effect the attenuation, and hopefully elimination, of the market conditions which created, and have sustained, multiple rent prepayments.

Keywords: Income redistribution; Landlord and tenant, Lagos real estate market; Market failure; Rent prepayment
\end{abstract}

\section{INTRODUCTION}

Economic decisions are governed by rationality. The parties to a business transaction commonly have the intention and expectation that value will be given and received. The assumed equality of strength amongst the willing parties does not preclude either party from seeking advantage. Each party is in search of what the other possesses and for which both are desirous of making an exchange. Buyer and seller, payer and receiver, both share this motivation no matter the level of scarcity of the article of trade. This scenario, which is in consonance with the principles of rational economic activity, applies to real estate transactions, whether buying, selling or letting. Being involved in a search for value, the parties to a real estate transaction come to an agreement with the understanding that value will be received by both. That being the case, it would not be 
possible that transactions between parties who have matching intentions and expectation could produce an outcome whereby value is fully given by one party, but is not fully received by the other. Transactions are generally sealed when the parties are satisfied that value can be received in exchange.

However, a situation of unequal exchange exists in the Lagos real estate market. This occurs in many lettings where a lessor demands and receives multi-year prepayments from tenants. The immediate and easily discernible effect of this entrenched practice is that value is fully and instantly given by one party, but is not equally received by the other, both in theoretical and practical terms. The lessor receives unearned value whilst the lessee receives value in deferral amounting to an unequal exchange. In some cases, the prepayments are for periods ranging from between two to five years and sometimes lengthier. This contradicts the assumed rationality in economic transactions. These demands are made in commercial, residential and industrial property lettings. The mismatch in giving and receiving value, with which this study is concerned, arises only in the letting sub-sector.

Whilst it is difficult to deny that multi-year prepayments are not burdensome to tenants, it cannot be claimed that they are not advantageous to landlords. Concern about the burdensome nature of the practice was recently expressed by Nigeria's Minister of Housing, as reported by Jannah (2018), pointing out the anomaly in one having to spend monies which have not been earned, and will not be, for years to come. The recession in the economy and the impact on disposable incomes of an inflation rate averaging 15\% may have been the reason for the minister's intervention and appeal to landlords to start accepting rent in arrear and on a monthly basis. This would mean tenants having to pay rents only after earning and receiving monthly income which is the normal order. The minister's statement suggests that the present practice is abnormal. This abnormal situation must, therefore, have implications and these need to be examined. This paper is an examination of issues of value and other implications of the practice especially for a country in search of human and economic development.

The paper argues that the practice has financial and socio-economic implications. Firstly, prepayments are financially unfavourable to those who are compelled to make them. Secondly, they challenge the logic of economic exchange which is based on the giving and receiving of value by the transacting parties at the same time. Thirdly, they also are unfavourable in respect to tenants' well-being. Fourthly, since an abnormality exists in this situation, implications cannot be ruled out for the economy.

The topic is important because it involves financial loss and gain, usually amongst the "haves" and "have nots", thereby denoting a redistribution of income between transacting parties. Furthermore, it has obvious, but as yet unmeasured effects on the economy. In addition, it is a human developmental issue impacting upon tenants' quality of life, conditions of living, their disposable income and potential to save. Thus, the practice seems to contradict government's claim to having an interest in "eradicating" extreme poverty and empowering the populace to live above the poverty line. Multi-year rent prepayments cannot in any guise advance the attainment of that objective given that an estimated $60 \%-80 \%$ (some times higher) of household income is spent on accommodation. The practice of multi-year rents is, therefore, a burden and threat to the survival of the estimated $80 \%$ of Lagos' population who live in rented accommodation. It is a livelihood and liveability problem.

The approach adopted in the study involves the assessment of the financial effects of multi-year prepayments from the viewpoints of landlord and tenant. This is done to establish where advantages and disadvantages lie. The calculations are made by use of valuation tables, specifically the compounding and discounting tables. Regarding the other implications of the 
practice, economic theory and practice are used to explain the potential effect on the economy and socio-economy.

Following this introduction, there is a rationalisation of rent from the viewpoints of landlord and tenant. This is followed by an overview of the Lagos letting market and advance rent payment practice; a discussion of its many implications follows thereafter. Then conclusions are drawn, followed by recommendations on the issues identified by the study.

This study is about the practice and implications of multiple-year rent prepayments, ranging from two to five years and sometimes longer. The focus is on residential property, although prepayment is practised also in respect of commercial and industrial property. The financial evaluations are made by valuation theory whilst other evaluations are made by secondary data.

\section{RENT AND ITS RATIONALISATION}

Property rent is contractually arranged; it is legally demanded and willingly paid. Motive lies behind the demand for, and the payment of, rent. Both parties in a letting transaction come with a motive. The transaction motive of the landlord is to receive adequate recompense for the service which the property will offer to the tenant. On the other hand, the tenant's motive is to deploy the value in the property to enhance his economic objective(s). The way in which this applies to commercial and industrial property is obvious because they are directly deployed in income production. However, it applies also to residential property which, even though not directly used to produce income, enables the process by meeting the fundamental shelter need of the producer. In computing production costs, the producer's residential shelter costs must feature for the assessment to be comprehensive and rent payment rationalised.

The tenant justifies rent payment by assessing the profitability of the property to him. In this regard, Fraser (1984) explains that prospective tenants rationalise rent payment on the basis of the profitability of occupying a particular location. Where there is evidence of a surplus of expected sales revenue over operating costs, including profit, there is sufficient reason for making a competitive bid for the use of such property.

This is the basis of decisions particularly in regard to business tenancies, a foundation which goes back to the theory of rent as a surplus. Property (land and improvements of land) being a factor input of production, people generally would agree to pay a particular rent for using a facility if at that size of rent their businesses would be profitable (or their motive(s) become achievable. Of course, profitability would be determined after having taken into account all business input (i.e. operating expenses and the tenant-investor's remuneration).If at any point it becomes unprofitable to remain in the premises, the rational response is for the tenant to leave the location.

The tenant's rational expectation is to benefit from value in the premises he intends to occupy. This should be in accordance with the same logic on which his business is run. Thus, if his business earns income on a certain basis, then he should logically pay the rent passing on the same basis. Where the tenant uses a building as residence for which he pays rent out of his monthly salary, the logic should be to pay the rent on the same basis on which he is remunerated in his employment. Normal businesses are run on the basis that they produce or sell goods or render services before receiving payment. For some businesses engaged in the supply of goods on credit terms, there will be a longer waiting period before payment is received from their clients. Besides, it is not normal practice for businesses to be paid years in advance of their production, delivery or sale of goods. Similarly, it is also not the norm for residential tenants, most of whom are in paid employment, to earn years in advance the incomes from which they pay their rents. The objective of the tenant, therefore, is to receive appropriate value which corresponds with the logic of the free market economy where the price mechanism is the basis of 
decision-making for all categories of economic actors. The pertinent basis of pricing and the assessment of value in the real estate market is the present value, not a future value which is uncertain. Thus, the apt value which a tenant in annual occupation should pay is one year's rent for each year of occupation and payable in each year of occupation. Logically, and equitably, value should be received before payment. But this would be possible if, and only if, rent is paid in arrears.

The landlord has his own motive(s) and justifications. By producing space and putting it out in the market place, the landlord is offering a service to the providers of other services and producers of goods in the economy. Since the landlord usually has no wish to use the property himself, his desire is to get another party to pay him for the use of the provided space. Thus, the landlord is an economic actor guided by the economic motive of earning investment income by satisfying a need. Accommodation is a need which is common to businesses, individuals and households. Landlords supply the space used for production, commercial activities and residence. Property is a long-term investment just as business and production are long-term undertakings. Therefore, a landlord who is astute to his own interests would not demand extortionate terms which make it difficult for the tenant to continue in business as this would constitute a risk to income security and regularity and his need for long-term value realisation. Such a risk would ensue through rent voids and vacancy. Overall, there is justification for making payment on the part of the tenant as there is justification for demanding payment by the landlord. Both parties act willingly to meet the needs of each other.

\section{THE LAGOS CULTURE OF MULTI-YEAR PREPAID LEASES}

Since multi-year prepayments are a characteristic of business and residential tenancies in the Lagos real estate market, it is necessary and important to consider the general features of its letting sub-market.

\subsection{The Lagos Letting Market}

The size of the market is not certain by any means, the absence of accurate and reliable data being the reason. However, six discernible factors suggest a very sizeable market, particularly for residential property, on which this study is focused. First, is the population size of the city which is 21 million (Lagos Bureau of Statistics, 2015). Secondly, between $60 \%-80 \%$ of this population is estimated to live in rented accommodation (Nwokoye, 2018).Thirdly, the city has a substantial housing shortage, estimated respectively at 2.5 million units(Lagos Bureau of Statistics, 2015) and 3 million units (RIRFHUD, 2016). Fourthly, the inadequacy (and unaffordability) of accommodation is reflected in homelessness and numerous informal settlements which as at 2007 numbered over 100 (Akinwuotu, 2015). Fifthly, the proportion of income spent on rent by tenants has been estimated to be as high as $60 \%$. (Aribigbola, 2008). There is no disputing that these conditions suggest potential. Sixthly, even though Lagos has a significant level of poverty, its 2015 annual per capita income at $\$ 4,333$ was vastly higher than the national average of $\$ 2,450$ (World Bank, 2014; Kingmakers, 2015).This advantage, is of course, conferred by the city's accommodation of over $50 \%$ of Nigeria's commercial activities, comprising businesses, manufacturers, financial institutions as well as small and medium enterprises (Ambode, 2017) which even as at 2014 collectively made a $25 \%$ contribution to Nigeria's non-oil GDP(Akabueze,2014).

\subsection{Rent Prepayment}


This is the practice whereby landlords demand that tenants pay in advance, rather than in arrear, the agreed rent on real estate leases. The period of payment is at the very least one year. But more usually the period of advance payment extends to as many as five years or more. These advance payments are made before entry into possession. Upon renewal of the lease, the same arrangement is often maintained. According to Sonaike(2017), "Advance house rent payment is a 'new normal' in the Nigerian property market wherein landlords and property owners demand two to three years house rent from tenants, mainly workers, who are paid salaries on monthly basis and also in arrears". This statement suggests that prepayment is a widespread and entrenched practice. It suggests also that there is an element of abnormality in demanding annual, biennial, triennial, quadrennial and even quinquennial rents from monthly paid tenants.

Money is the reward earned after exertion. There is an obvious anomaly in multiple rent prepayment practice since there is no free money to be found anywhere. This means that money which is paid as advance rent comes from somewhere and at a cost. The cost of money is the interest rate, meaning that where money is released from one party to the other, there is a cost involved in the shape and form of interest. The logic is that incomes have to be earned before they can be spent. Prepayment reverses this logic. Landlords, as the receivers of prepayments, present the argument that they suffer a disadvantage in that the practice ties them down to a fixed rent for the period in question. This means that they will not be able to benefit immediately from any rental value appreciation during the subsistence of the prepaid rent. Thus, they view the arrangement as being advantageous to the tenant. But the fact that the landlords were not forced into the arrangement by prospective tenants means that landlords see only advantage, not disadvantage, in prepayments. If a disadvantage exists, then they clearly consider this as being less than the inherent advantage. Nonetheless, as Omidire (2015) reports, Stanbic Real Estate Finance points out that: "The 1-5 year up front rent structure removes the ability for an asset to appreciate or outperform... Landlords think they are securing their income by collecting so many years up front, but instead they are putting a cap on growth of future cash flows, locking them in. If there is an increase in rents, you will be effectively locked into a certain value for up to 5 years. What about escalations? I'll tell you that in a market like Nigeria, escalations of $5 \%-10 \%$ ? might not always outperform the market". Obviously, the persistence of prepayment means that landlords do not consider these points as being sufficiently important. But is the "loss" incurred by the landlord greater than the loss of the tenant from prepayment? That issue is considered in section 4 of this paper.

Additionally, the argument has been presented that landlords demand multiple prepayments because of the pressure to repay loans raised to finance their projects: "high interest rate charged by lenders on housing loans and the short period of repaying such loans" (Sonaike, 2017) are the reasons for the advance house rent "demanded by landlords and/or property owners from prospective and even sitting tenants". This position is difficult to sustain for three reasons. First, mortgage installments are not paid in advance. Furthermore, prepayment is practised also by landlords who do not use loans to build and these might well be in the majority considering that mortgages are few and far between. Again, mortgagees do not demand multiple repayments by mortgagors. A mortgagor can come under pressure of foreclosure if he has been irregular in payment and consequently accumulates arrears through the operation of compound interest.

Rents in Nigeria, particularly Lagos, have not always been paid in advance or annually for residential property. The practice was monthly payment in arrears. Multiple rent prepayment for real estate (commercial, residential and industrial) took root in Lagos of the 1970s during Nigeria's first oil boom period. Given the 1970s scenario of rapid urban-rural migration consequent upon the oil boom, Lagos experienced a rapid population growth, leading to accommodation shortages. The availability of petro-dollars and the then military government's 
ill-advised, across-the-board increase in salaries of public servants meant a rising money supply and inflation. In the midst of shortages, the oil boom created a rent boom. Landlord's naturally sought to earn more due to rising demand and slow supply.

Before the 1970s, Nigeria was an agrarian economy to whose GDP agricultural production made an average contribution of $64 \%$ in the 1960 s. The contribution declined to $48 \%$ in the 1970 s (Izuchukwu,2011) with the coming of the oil boom and consequent neglect of the agricultural sector. Before the 1970s, Nigerians did not have the purchasing power which was to come with the oil boom. Neither did Lagos experience the severe accommodation shortages and infrastructural inadequacies which started to manifest in the same period. Therefore, prepayment practice did not ordinarily exist. It is, however, a fact that before the 1970s, multiple rent prepayment was practised by only oil producing and marketing companies operating in Nigeria such as BP West Africa later BP (Nigeria), Shell, Texaco, Esso and Agip, all foreign. These firms practised advance payments of ten or more years for land taken on long leases for the development of petrol-filling stations, office premises, tank farms and production installations. The companies preferred leases as they did not have a corporate tradition of owning property unlike the situation today. These long-term advance payments were rationalised in part by the long-term nature of their investment. Furthermore, the risk and uncertainty in the oil business did not advise being tied to business locations through property ownership. Thus, leases were preferred and prepayments made for long-term planning. The difference between then and now is that landlords did not demand those payments, rather the oil companies offered to make them.

\section{FINANCIAL ISSUES ARISING BETWEEN LESSOR AND LESSEE}

The most measurable, and therefore, the most direct effects of multiple prepayment are reflected in the post-transaction situations of tenant and landlord. This section explains the financial effects on the transacting parties, whilst the economic and socio-economic impacts are considered in the subsequent section.

Regardless of whether the objective is to buy, sell or lease, the search for value is the basis of real estate transactions. This search is seen to yield results if, and only if, value in exchange is received by both parties. In lease transactions, this desire exists on the side of the landlord and his prospective tenant(s).Thus, the desire to obtain value cannot but be the reason for the demand for advance rent payments. But can this be also the reason for the tenant(s) agreeing to pay in advance of enjoyment of the premises? If this is not the case, then one party is getting less value for money. Proof of this assertion is presented in section 3.

The usual response of benefitting landlords and their agents is that the market is ruled by demand and supply. This seems to be an admission that prepayment practice is founded upon, and sustained by, the failure of the industry to increase production in response to demand, and thereby, bring about an equilibrium situation. Furthermore, there is the suggestion that multiple prepayments are opportunistic. Again, the landlords' argument merely confirms the thesis of a delivery of unequal exchange, rather than value in exchange, between the transacting parties.

The easy availability of affordable mortgages which Sonaike (2017) proffers as a solution may not prove to be so. This is because making a lasting impact on a 2015 shortfall of 2.5 million units (which, of course has not been static since 2015) requires a minimum of 200,000 units yearly, which mortgages alone cannot provide. Additionally, there are issues such as access to land, acceptability to lenders of non-statutory land titles which are in the majority, the cost of construction and the level of savings of individuals and households who may choose the route of owner-occupation. In addition, the actuality of poverty amongst a sizeable 1.7 million or $8.5 \%$ of the Lagos urban population (NBS, 2018) is exacerbated by a new (2019) national minimum 
wage of US\$100.00, but which is yet to be implemented as at October 2019 since its approval in May 2019.

It is, therefore, important and necessary to examine how value is practically received or lost, as the case may be, in transactions involving multiple prepayments between a lessor and a lessee. Four situations are examined. First, how the inequality arises; secondly, how value is lost by the tenant; thirdly, how the landlord may possibly lose some value due to forfeited rent reviews; and lastly, how the inequality in the transaction may be minimised. The compounding and discounting factors are taken from Parry's Valuation and Conversion Tables (Davidson, 1980).

The practice is tantamount to an unequal exchange which implies that there is a loser and a winner. This inequality is displayed in Tables 1, 2 and 3 which consider a transaction between two parties. The assumptions made are as follows: A lease term of 5 years effective 1.1.2018, at an annual rent of N1, 000,000-00 which is payable fully in advance upon taking possession. It is further assumed that the tenant funded the payment from his savings account on which he was earning interest at the rate of $10 \%$ per annum. Similarly, the landlord invests the received funds in his savings account at the same rate.

Table 1: Value Received by Landlord from Rent Prepayment

\begin{tabular}{|l|l|l|l|l|l|l|l|}
\hline Start & End & $\begin{array}{l}\text { Rent } \\
\text { Amount } \\
(\mathrm{N})\end{array}$ & $\begin{array}{l}\text { Total Rent } \\
\text { Received } \\
(\mathrm{N})\end{array}$ & $\begin{array}{l}\text { Amount of } \\
\text { N1 in 5years } \\
\text { @ 10\% }\end{array}$ & $\begin{array}{l}\text { Value To } \\
\text { Landlord }\end{array}$ & Profit (N) & $\begin{array}{l}\text { As \% } \\
\text { of } \\
\text { Total }\end{array}$ \\
\hline 1.1 .18 & 31.12 .22 & $1,000,000$ & $5,000,000$ & 1.6105 & $8,052,500$ & $3.052,500$ & 61.05 \\
\hline
\end{tabular}

The landlord receives the sum of N5million as value in advance for delivering a service(facility) which would give the tenant value over a 5-year period, but the fact of advance payment creates the opportunity of investing the funds to yield N8,052,500 (a profit of $61.05 \%$ ) over the same period. The extent to which the landlord benefits can clearly be appreciated.

Table 2: Value Lost by Tenant

\begin{tabular}{|l|l|l|}
\hline $\begin{array}{l}\text { Sum Borrowed by } \\
\text { Tenant(N) }\end{array}$ & $\begin{array}{l}\text { Amount of N1@10\% for 5 } \\
\text { Years }\end{array}$ & $\begin{array}{l}\text { Cumulative Sum at end of } 5 \\
\text { Years }\end{array}$ \\
\hline $5,000,000$ & 1.6105 & $8,052,500.00$ \\
\hline & Less value paid for: & $5,000,000.00$ \\
\hline & Loss incurred by Tenant & $3,052,500.00$ \\
\cline { 2 - 3 }
\end{tabular}

The loss incurred by the tenant is equivalent to the gain of the landlord. There has, in effect, been a transfer of value equivalent to a redistribution of resources. However, the argument can be made that the landlord also loses out by forfeiting his right to have the rent reviewed every two or three years as is the practice. But this argument assumes that rents can be reviewed only upwards to the advantage of the landlord. It is not impossible, however, for the revision to remain static, be renegotiated or go the other way in a declining market as has been experienced in Lagos since the 2015 recession in Nigeria. Nevertheless, it is necessary to consider the size of the Landlord's potential loss from forfeiting the right to an upward revision and the economic significance of the loss by making a comparison with his actual gain and the tenant's loss. Table 3 assumes that the rent agreed and paid in year one will fall due for an upward revision at the 
end of the third year and that the reviewed rent will subsist for the remainder of the lease period. In effect, the landlord has only one opportunity to review the rent upwards.

Table 3: Landlord's Loss from Forfeited Rent Revision

\begin{tabular}{|l|l|l|l|l|l|}
\hline $\begin{array}{l}\text { Year of } \\
\text { Lease }\end{array}$ & $\begin{array}{l}\text { Assumed } \\
\text { Rent } \\
\text { Review }\end{array}$ & $\begin{array}{l}\text { Rental Value } \\
\text { at Start of Each } \\
\text { Yr. }(10 \% \\
\text { Growth p.a. }\end{array}$ & $\begin{array}{l}\text { Rental Value } \\
\text { at End of Each } \\
\text { Yr. (10\% } \\
\text { Growth p.a. } \\
4\end{array}$ & $\begin{array}{l}\text { Actual Rent } \\
\text { Received by } \\
\text { Landlord (N) }\end{array}$ & $\begin{array}{l}\text { Rental Value } \\
\text { less Rent } \\
\text { Received(Col } \\
4 \text { less Col 5) } \\
6\end{array}$ \\
\hline $\begin{array}{l}\text { Year } \\
1(1.1 .2018- \\
31.12 .2018)\end{array}$ & - & $1,000,000$ & $1,100,000$ & $1,000,000$ & 100,000 \\
\hline $\begin{array}{l}\text { Year } \\
2(1.1 .2019- \\
31.12 .2019)\end{array}$ & - & $1,100,000$ & $1,210,000$ & $1,000,000$ & 210,000 \\
\hline $\begin{array}{l}\text { Year } \\
3(1.1 .2020- \\
31.12 .2020)\end{array}$ & 31.12 .2020 & $1,210,000$ & $1,331,000$ & $1,000,000$ & 331,000 \\
\hline $\begin{array}{l}\text { Year } \\
4(1.1 .2021- \\
31.12 .2021)\end{array}$ & - & $1,331,000$ & $1,464,100$ & $1,000,000$ & 464,100 \\
\hline $\begin{array}{l}\text { Year } \\
5(1.1 .2022- \\
31.12 .2022)\end{array}$ & - & $1,464.100$ & $1,610,510$ & $1,000,000$ & 610,510 \\
\hline
\end{tabular}

It is established in the table that rental value appreciates annually at the rate of $10 \%$, producing a gross benefit of N641,000 which the landlord loses for the first three years(1.1.2018 to 31.12. 2020) because he has received N3,000,000 in advance, rather than annually. Over the same three yearperiod, the actual receipt of N3,000,000-00 if invested by the landlord at a return rate of $10 \%$ produces N3,993,000-00(N3,000,000 multiplied by 1.331 or Amount of N1 @ 10\% for 3 years). This return of N993, 000 is larger than the N464, 100 cumulative rental growth not received. Similarly, for the whole term, the cumulative rental growth of N610, 510 is lower than the yield from investing the N5million advance rent (N3.052, 000).Since the lease provides for a rent revision after thee years, the landlord will be entitled to receive $\mathrm{N} 1,331,000$ for the last two years, but this is only N33, 000 larger than the N200, 000 received as prepayment for the period. If N200, 000 is invested at $10 \%$ over 2 years, the yield would be only N242, 000, only N42, 000 larger. Thus, the landlord's gain is far more than his supposed loss.

\subsection{Improving Equity in Prepayment Transactions}

In theory, the inequity can be eliminated if payment were to be made daily as the tenant uses the property. This theoretically means that the tenant receives value the same time as the landlord gives value. However, this is cumbersome and impracticable in modern society and for modern businesses which require planning. Nevertheless, it is possible to lessen the inequity in by using the present value factor to discount yearly the annual prepaid rents and deducting the cumulative value to arrive at a fair total prepayment which ought to be made by the tenant at the commencement of the lease. Table 3 explains this approach using the same assumptions. It is further assumed for simplicity that rent is to be paid fully at the beginning of each new term.

Table 4: Reducing Inequity in Multi-Year Prepayment Transactions 


\begin{tabular}{|c|c|c|c|c|c|c|c|}
\hline Year & $\begin{array}{l}\text { Rent } \\
\text { Paid(N) }\end{array}$ & $\begin{array}{l}\text { Date for } \\
\text { Receiving } \\
\text { Value }\end{array}$ & $\begin{array}{l}\text { No. of } \\
\text { Yrs. }\end{array}$ & $\begin{array}{l}\text { PV } \\
\text { factor@ } \\
10 \%\end{array}$ & $\begin{array}{l}\text { Adjusted } \\
\text { Value(N)C } \\
\text { ol. } 2 * \text { Col. } \\
5\end{array}$ & $\begin{array}{l}\text { Differenc } \\
\text { e or Loss } \\
\text { of Value } \\
\text { by } \\
\text { Tenant }\end{array}$ & $\begin{array}{l}\text { As } \% \text { of } \\
\text { Total } \\
\text { Payment }\end{array}$ \\
\hline 1 & $1,000,000$ & 1.1.2018 & 0 & 1 & - & 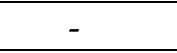 & \multirow{6}{*}{16.60} \\
\hline 2 & $1,000,000$ & 1.1.2019 & 1 & 0.9090909 & $909,090.9$ & $90,090.09$ & \\
\hline 3 & $1,000,000$ & 1.1 .2020 & 2 & 0.8264463 & $826,446.3$ & $173,553.7$ & \\
\hline 4 & $1,000,000$ & 1.1.2021 & 3 & 0.7513148 & $751,314.8$ & $248,685.2$ & \\
\hline 5 & $1,000,000$ & 1.1.2022 & 4 & 0.6830135 & $683,013.5$ & $316,986.50$ & \\
\hline Totals & $5,000,000$ & - & - & - & - & $830,134.5$ & \\
\hline
\end{tabular}

The overpayment by the tenant is N830, 134.5 which is approximately $17 \%$ of the entire prepayment. This is his cumulative loss as a result of paying N5 million in advance at once rather than paying N1 million at the start of each new tenancy. The inequality in advance rent payments will be reduced if there is a provision for mitigating the tenant's loss by deducting it from the prepayment. In this case, rather than paying

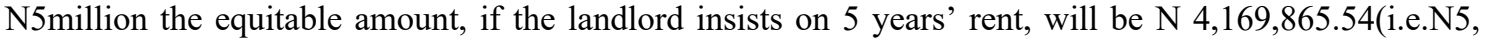
000,000-00 less N830, 134.46). Therefore, the tenant loses out where multiple prepayments are demanded of him.

\section{OTHER ISSUES ARISING}

In addition to the measurable and direct financial effects on the lessor and lessee, there are potential, unintended socio-economic and human developmental implications for tenants (whether individuals, organisations or households) as well as the economy.

\subsection{Economic Planning}

The payment of rents in advance and for so many years, is likely to lead to a high money supply with implications for the general price level. Considering Lagos' 25\% contribution to Nigeria's GDP (Akabueze, 2017), this presents a challenge to monetary policy effectiveness. Controlling the money supply in an economy enables appropriate pricing of the factors of production.

Development is the goal of economic planning. This happens when there is a transformation of society such as leads to improvements to the lives of citizens through uplifting their economic status and quality of life. This is the desire of all progressive societies. Economic planning aims at mobilising and deploying available resources to advantage in order to secure development that is real, effective and sustainable. It is important that each economic sector, real estate inclusive, plays its part in the delivery of economic development.

As the compass to development, economic planning should envisage a system in which factors of production and the various sectors are able to receive their due reward. The price mechanism plays the part of ensuring that (realistic) relative prices form the basis of decisions regarding the production of goods and the distribution of goods and services. The indications are that the practice of prepayment cannot aid the attainment of this objective. Rather, it has some implications at the macroeconomic and microeconomic levels.

It is important that the resources available in an economy are employed in a manner which would work to ensure commensurate returns to all factors and sectors engaged in the production of goods and services. Real estate is a (produced) good and also a (supplied) service. As a produced good, it is deployed in the production of all other goods; whilst as a service it is used in the supply of virtually all services. Its producers and suppliers need to be appropriately rewarded. This comes through payments made by customers whose wants are satisfied. The satisfaction of want is guided by the price mechanism which determines the appropriate reward to economic actors. The reward must be appropriate and realistic. Where, therefore, multiple prepayments occur, the reward for enterprise will tend to be abnormally for the letting sub-market. The returns are abnormal because they come earlier and, by the logic of time value are, therefore, more sizeable than they ought to be. This unusual situation portends some consequences. For the economy, these would come in the following ways. 
First, investment is a function of the level of savings in an economy, particularly the ability to mobilise such savings for investment by the right people and for use in the required sectors. Now, rent prepayments divert resources (earned and unearned incomes and loans) from prepaying tenants to property owners, who may divert such incomes, not to savings or the production of more accommodation, but to consumption. The level of investment would, therefore, be lower because savings levels are lower.

Secondly, these prepayments constitute abnormal pricing. The role of price in economics gives some justification to the definition of economics as the science of pricing. Normal pricing ought to reflect producer and supplier costs, not producer and supplier whims. Prepayments mean that the letting sub-sector of the real estate market is rewarded abnormally because the reward is not the result of increased productivity or efficiency. Ideally, the unusual advantage of prepayments should lead to increased production as more investors are attracted to the sector. That this has not been the case for decades and prepayments have persisted, suggests a situation of market failure. The persistence of prepayments means that all the sectors of the economy are not rewarded on the same basis: the real estate industry (the letting sub-market specifically) is rewarded in advance whilst others, which are no less productive, are not. This is not an ideal situation.

Thirdly, the cumulative effect of prepayments means that funds which otherwise would be out of circulation by being kept as savings or used for productive investments would be diverted from such uses and put into circulation, thereby increasing the money supply. An increasing money supply which is not due to increases in production obviously must impact upon the general price level in the form of rising inflation. This would be especially so because landlords may choose to spend such funds on non-capital goods which do not contribute directly to wealth creation unlike machinery, equipment and buildings. Higher inflation rates portend lower real incomes, a lower standard of living and a greater likelihood of rising poverty and social dislocations.

Fourthly, the implication of an entrenched system of advance payments is that there is a situation of unlicensed, unofficial and, therefore, unauthorised lending of money by tenants to landlords. These sums are undocumented, but would be undoubtedly significant, if aggregated. The payments are not officially captured as loans and give an undue advantage to lessors. Officially, the lending of money is formally done by licensed financial institutions who are guided by law. Advance payments effectively by-pass the extant laws on lending. This widespread practice makes impossible the collation of accurate data on the level of lending in the economy, an important consideration in economic planning and performance appraisal. Again, the lack of data on this and other property market issues is connected with the poor information flow characteristic used by Jones Lang LaSalle (2016) to categorise Nigeria's property market as being opaque, a status which was upgraded to "low transparency" in the most recent survey Jones Lang LaSalle( 2018).

Fifthly, prepayments have an income redistribution effect, albeit unplanned, unofficial and misdirected. The upshot is that "have-nots"(non-property asset owners) transfer their resources to the "haves" (property asset owners). This is unlikely to do anything to reduce Lagos' high poverty rate. Therefore, human and social development is put at risk.

On the smaller scale, prepayments produce behavioural consequences for tenant and landlord, but in different ways. Prepayment practice prevents and discourages savings by tenants. By so doing, it prevents investment. If households do not save and invest, they will find it difficult to build up assets and income for socio-economic upliftment. The unsatisfactory situation of tenants spending a substantial portion of their income on accommodation is made worse by their taking loans to pay rents years in advance for new leases and renewals, thus losing the opportunity to make savings for investment. In Arigbibola's (2008, p126) survey of the city of Akure which has lower average rents and per capita income than Lagos, $37 \%$ of the sample of households spent between $30 \%-60 \%$ of their income on rent. More disturbing is the finding that $17.7 \%$ respondents spent about $60 \%$ to $90 \%$. It boggles the mind what tenants have left to live on, what quality of life they enjoy, and what prospects they have of owning their own homes. It is no wonder that the poverty rate continues to rise.

Furthermore, a high percentage of Lagos residents live in rented accommodation. Research by Adediji (2009) puts the figure at $60 \%$ of households whilst Nwokoye as reported by Nweke (2019), estimates that $80 \%$ of Lagos' residents occupy rented accommodation, spending about $50 \%$ of their incomes on rent. Now, with Lagos having a 2015 estimated population of 21 million (Lagos Bureau of Statistics, 2015) of which $8.5 \%$ or 1.7 million people live in poverty (NBS, 2018), this suggests that multiple year prepayment practice is most likely to accentuate human and social problems. Nwokoye (2019) adds that the problem of housing inadequacy is made worse by the unapproved conversion of residential buildings to commercial 
use, thus further reducing the numbers of residential accommodation in the market. This is a reflection of weak planning control and inappropriate zoning laws in an environment of rapidly rising population and relatively low supply of new housing.

The receipt of unearned payments by landlords from tenants amounts to a redistribution of income. The income received is more than the value delivered. This is a situation which promotes inequality in society as resources are transferred from predominantly economically unestablished members to principally economically established members. As the recipient of unearned incomes and beneficiary of an unintentional income redistribution, the landlord occupies a privileged position. Depending on his abilities and priorities, he may be motivated either to deploy his financial advantage to more production or go into wasteful spending. The landlord is entitled to enjoy the income from his investment, but not to receive it before the due date.

\subsection{The Housing Deficit and Economic Development}

Residential accommodation (shelter) is a basic human need and its adequacy is vital to good health, wellbeing and productivity. Lagos has an acute shelter problem as seen in the sizeable housing shortfall and the existence of numerous informal settlements. The housing shortfall in Lagos is given respectively as being between 2.5 and 3 million units according to (Lagos State Bureau of Statistics, 2015) and (RIRFHUD, 2017).To redress this requires the sustained production of over 200,000 units per annum. Now, the bulk of production comes from individuals who invest mainly in build-to-let single unit buildings or flats. In addition, speculative corporate developers produce built-for-sale estates whilst Lagos state has a policy for building estates for sale, but mainly for the middle and lower end. There are also individuals and household who build and occupy their own dwellings after years of living as tenants. Though not officially documented, this category contributes to reducing the housing shortfall. People in this category are able to succeed because of their ability to save in order to buy land, subsequently building in stages and over varying lengths of time, mostly without a mortgage. Some such people who are employed in structured organisations are able to obtain employee loans. The opportunity and capacity to save is the foundation to producing owner-occupied housing. Thus, where individuals and households are faced with committing as much as $60 \%$ of their income towards rent, the capacity to save will be severely limited. The implication for economic development is that property being a factor of production, an increase in housing supply will produce an increase in productivity. In the contrary case, economic productivity will slow down because property as a factor input is limitedly available. Thus, the rent prepayment burden, by effectively preventing more production hinders economic productivity and thus slows the rate of economic development.

\subsection{Social Impact}

There are social consequences to tenants to being obliged to pay rents in advance.

First, poverty is a social problem, the basic manifestation of which is an inadequate level of income for sustenance. This instantly implies a low living standard. The high poverty level in Nigeria has been revealed by many recent reports (World Poverty Clock, 2019; World Bank, 2018; IMF, 2018; African Development Bank, 2018). According to The World Poverty Clock over 91 million are living in abject poverty (i.e. those living on less than $\$ 1.9$ per day) whilst the World Bank gives the number living below poverty as 92.1 percent. African Development Bank's estimates that $80 \%$ of Nigerians live below the poverty line. The IMF (2018) also reports that Nigerians are getting poorer. Using a poverty measurement yardstick of N2, 000 (or \$5), the World Bank estimates that (approximately 90 million persons and half of the estimated total population) live below this level, the worst record amongst the nations of the world. The report also reveals Nigeria as having the greatest numbers of extremely poor people in the world (those living on less than $\$ 1.90$ per day). Even with the newly approved national minimum wage, the challenge of inadequate disposable income remains, given the disproportionate amount which households spend on rent (Nwokoye, 2019). Thus, a typical household of seven persons which earns N2, 000 (or $\$ 165$ per month and spends $50 \%$ of it on rent, would have only $\$ 45$ for food and clothing (two other basic needs) and utilities and other expenses. The obvious effect is a low standard of living and the entrapment in poverty. This becomes glaring if it is recalled that the recently approved national minimum wage of N30, 000 per month amounts to approximately only $\$ 90$.

Secondly, a sizeable segment of the population would become socially excluded. People and households who are unable to cope with prepayments for formal housing will seek alternatives in informal settlements, thereby fuelling the rate and spatial distribution of slum growth. In Lagos, an estimated $65 \%$ of the population lives in slums and squatter settlements whilst "some 300,000 plus Nigerians are homeless....due 
to state-ordered demolitions and a lack of space" (Borgen Project, 2018). Informal settlements, according to Arimah (2001) are indicative of social exclusion. This situation has been aggravated by state-ordered demolitions of informal settlements and slums without any compensation or resettlement, thus driving the evictees further into poverty. The rent prepayment culture is a driver of the informal settlements which dot the Lagos metropolis, the number of which Akinwotu (2015) estimated at being over 100 as at 2007.

Thirdly, the pressure to meet deadlines for prepayments has the potential of leading people into dishonest behaviour and sharp practices. Thus, the pressure of advance payment is potential driver of corrupt practices and crime in society.

Fourthly, tenants may suffer anxiety as the payment deadline approaches, producing implications for mental and physical health. According to the Borgen Project (2018) "economic inequality has been an ongoing battle in Lagos for years" and prepayment is a factor which accentuates its effects.

In the preceding examinations of the multiple rent prepayment practice in the Lagos letting market, the following have been revealed. First, prepayments prematurely deliver money into the hands of landlords whilst it compels tenants to spend money which they are yet to earn. It is completely tantamount to consumption before production; instantaneous gratification on the part of the landlord, rather than proportionate and gradual gratification. This advantageous situation to the landlord is, however, represents a distortion from the viewpoint of the appropriate reward for a factor of production, which land and buildings comprise.

Furthermore, companies and households who are compelled to make such payments, incur avoidable costs as well as lose liquidity over their funds, probably drawn from savings(meaning forfeited interest) or borrowed at a cost (meaning incurred interest), all of which represent cost since the interest rate is the price of money, no matter how sourced.

Additionally, there is a risk of such prematurely paid money either ending up as idle money (i.e. not put to any productive use) and, therefore, likely to be spent recklessly. The ideal use for such money would be to apply it to produce more housing so that it does not create an inflationary impact in the economy. At the present time, there is, however, no way of knowing how such money is treated by its recipients.

Regarding the economy, prepayments will tend to reduce the level of saving through the implied diversion of potential saving of the paying parties. Again, the potential contribution of payers to reducing the housing shortfall by saving for building their own houses is reduced.

In terms of value for money, prepayments have been shown not to favour the payer whilst it does the receiver. The landlord receives a higher value without doing anything extra for the tenant; the tenant loses value and there is a financial inequality which is not put into consideration at all. It cannot be discountenanced that producer-tenants who have to pay rents in advance will surely try to recover the implied extra (hidden) cost through the pricing of their output. Thus, there is an implied likelihood of higher product and produce prices in the economy. This will mean that the higher rents paid to landlords will be borne ultimately by consumers, not the producer-tenants. The attempt to reduce the inequality (Table 4) appears to solve the problem because the tenant is able to take into account the time value of money as well as the interest rate. This is all well since the approach acknowledges that the interest rate is the cost of money (to which the tenant is committing himself by prepaying the rent) and the basic principle which states that value of an investment is the sum of the present value of expected future income flows. However, this does not satisfactorily solve the problem of inequality. This is because the tenant is burdened and compelled to make an unnecessary and avoidable outlay.

\section{PRACTICAL IMPLICATIONS}

There are implications at the levels of the individual, the society and the economy. Individually, investors in property occupation lose substantial sums to investors in property ownership. At the societal level, those compelled to make prepayments are financially burdened such that they are challenged in terms of progressing towards home ownership and improvement in socio-status, with implications for poverty alleviation policies. At the level of the economy, the money in circulation will tend to rise with implications for the general price level and there is an instantaneous and continuing redistribution of income from the 'haves" to the "have nots'. Rent prepayment practice, being a situation of abnormal pricing, is indicative of market failure which requires government intervention.

\section{CONCLUSION}


This study set out to assess the practice whereby tenants pay rent many years in advance of the actual enjoyment of leased premises. The conclusion is that the practice financially benefits landlords more than tenants. Furthermore, the practice has other disadvantages to tenants and presents difficulties for the economy.

The findings are that the landlord has a cumulative massive gain which is exactly equivalent to the tenant's cumulative loss, suggesting a redistribution of resources. Furthermore, the landlord's loss from a mid-term forfeited rent review is far lower than the gain from the advance payment. In addition, the tenant's loss can be reduced if the prepayments are discounted to present value at the time of payment. Finally, there are economic and socio-economic implications to prepayment practice.

The findings mean that landlords seek advantage in demanding multiple prepayments because they can reinvest these sums to produce substantial returns. This advantage to landlords may constitute a disincentive to their engaging in new production which has the potential of increasing supply, reducing competition, and consequently, rents. It also means that the real estate industry is inefficient by being unable to respond to pent-up demand through greater productivity; that the economy inefficiently and overly rewards producer-landlords regardless of the level of output. Whilst this may be partly due to systemic issues such as access to land and development finance, the persistence of abnormal pricing in the letting market means that the contribution of property to economic development would be sub-optimal. In addition, the absence of data on prevalent rent prepayments is a gap which needs to be filled for effective policy-making. Finally, the practice presents a challenge to poverty alleviation and social and human development policies.

This study recommends that government intervenes in the housing crisis by providing measures of enablement to the private sector whilst also introducing social housing, low cost mortgages and easier access to land. Through these steps, the shortfall can to be reduced to a level where urban residents who seek rented accommodation are not faced with the Hobson's choice of giving value in advance and receiving the same in deferral. This precludes legislation against the practice because such would not only be near impossible to implement as has been the case with rent control legislation, but also, likely to produce unhelpful consequences.

\section{REFERENCES}

Adediji, B. (2009).The State of Lagos Housing Market 2009. Lagos: Roland Igbinoba Real Foundation for Housing and Urban Development. www.rirfhud.com

African Development Bank (2018).African economic outlook 2018. Available at: https://www.afdb.org $>$ afdb

Akabueze (2017). Akabueze, B.I. (2014). Lagos contributes a quarter of Nigeria's gdpcommissioner, ChannelsTV, Available at: www.channelstv.com(Accessed 19 July, 2017)

Akinwotu, E. (2015).The forced evictions of Badia east, Lagos: this is not right. The Guardian, October 16. Online). Available at: https://www.theguardian.com/cities/2015/oct/16 (Accessed 14 January, 2017)

Ambode, A. (2017). Lagos GDP Hits $\$ 131$ Billion, News of Nigeria, 3 July. (Online). Available at: www.newsofnigeria.com. (Accessed 25 June 2018)

Aribigbola, A. (2011).Housing affordability as a factor in the creation of a Sustainable environment in the developing world: The example of Akure, Nigeria. Journal of Human Ecology 35(2)121-131

Arimah, B.C. (2001).Slums as expressions of social exclusion: explaining the prevalence of slums in African countries. OECD International Conference on Social Cohesion and Development, Paris, 20-21, 2011.scholar.google.com

Borgen Project (2018).10 facts about poverty in Lagos. https://borgenproject.org/poverty-lagosnigeria(Accessed 24 February 2019) 
Davidson, A.W. (1980).Parry's valuation and conversion tables. London: The Estates Gazette.

Fraser, W.D. (1984). Principles of property investment and pricing. London: Macmillan.

IMF (2018).Nigerians got poorer in Muhammadu Buhari's first term-Baba go slow. The Economist, $30^{\text {th }}$ May. (Online).Available at: $w w w$.the economist.com $>$ Nigeria (Accessed 17 September, 2019).

Izuchukwu, O.I. (2011). Analysis of the contribution of the agricultural sector to Nigerian economic development, World Review of Business Research 1(1), 191-200

Jannah, C. (2018).Fashola directs landlords to start collecting rent in arrears. Daily Post 6 July.

Available at: http://dailypost.ng/2018/07/06/fashola-directs-landlords(Accessed 24 February 2019)

Jones Lang LaSalle (2016).Global Real Estate Transparency Index 2016Available at: https://www.j1l.co.in

Jones Lang LaSalle (2018).Global real estate transparency index 2018. Available at: https://joneslanglasalle.com.cn

Lagos State Bureau of Statistics. (2015). Lagos State Bureau of Statistics. Home. Available at: www.lagosstate.gov.ng (Accessed 17th July 2017).

National Bureau of Statistics (2018).Available at: https://.www.nigerianstat.gov.ng

Nweke, M. (2019).Estate surveyor decries conversion of residential houses to commercial property. The Sun (Online). $1^{\text {st }}$ February. Available at: www.sunnewsonline.com

(Accessed 1st February, 2019)

Omidire, D. (2015). Opinion: 6 Challenges facing the Nigerian REIT Industry. Estateintel, 18 February. Available at: https://estateintel.com/opinio(Accessed 8 August, 2019)

Real Foundation for Housing and Urban Development. (2016). State of the Lagos housing market report. Available at: www.rirfhud.com. (Accessed 14th June 2018)

Sonaike, O. (2017).High interest rate, short tenor loans fingered for advance house rent. Housingnews, 29 June. (Online). Available at: http://www.housingnews.org.ng/m/highinterest-rate-short-tenor(Accessed 17 April,2019)

World Bank (2019). Nigeria-World bank data. World Bank Group. Available at: www.data.worldbank.org. (Accessed 27the May, 2019)

World Data Lab (2019).The percentage of Nigerians living in extreme poverty could increase by 2030. World poverty clock. Available at: $\underline{w w w . w o r l d p o v e r t y . i o}$ 